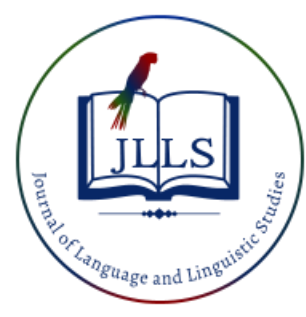

Available online at www.jlls.org

JOURNAL OF LANGUAGE AND LINGUISTIC STUDIES

ISSN: 1305-578X

Journal of Language and Linguistic Studies, 16(3), 1320-1333; 2020

\title{
The role of literature and literary texts in an EFL context:
}

\section{Cultural awareness and language skills}

\author{
Chomphu Isariyawat $^{\text {a }}$ iD, Chaleomkiet Yenphech ${ }^{\text {b }}$ iD, Kampeeraphab Intanoo ${ }^{\text {c1 }}$ iD \\ ${ }^{a}$ Buriram Rajabhat University, Buriram, Thailand \\ ${ }^{b}$ Mahachulalongkornrajavidyalaya University, Bangkok, Thailand \\ Buriram Rajabhat University, Buriram, Thailand
}

APA Citation:

Isariyawat,C., Yenphech, C. \& Intanoo, K. (2020). The role of literature and literary texts in an EFL context: cultural awareness and language skills. Journal of Language and Linguistic Studies, 16(3), 1320-1333.

Submission Date:21/04/2020

Acceptance Date:23/05/2020

\begin{abstract}
This research was aimed to 1) investigate the attitudes of learners towards literature, and 2) discover the impact of literature and literary texts on cultural awareness and language skills in Thai EFL undergraduate students. A blend of qualitative and quantitative research configuration was embraced. An abstract content was coordinated into an EFL class with 100 English major students at Buriram Rajabhat University. It is one of universities in the Northeast of Thailand. The samples were chosen by a simple random sampling method. Semi-structured interviews were done with the illustrations by the analyst. The discoveries of the research showed consistency between the participant Thai EFL students' points of view. They all pointed out the advantages of utilizing literature and literary texts as integrating students' cultural awareness and language skills.
\end{abstract}

(C) 2020 JLLS and the Authors - Published by JLLS.

Keywords: cultural awareness; language skills; literary texts; personal reflection; teaching English

\section{Introduction}

The most state-of-the-art scarcely any decades have seen a creating energy for the upsides of associating the instructive of an obscure highlight to the examination of its literature. The connection between the instructing of English language and literature was not generally smooth however. In the language classroom, there were additionally snapshots of reliable dismissal of the estimation of literature. In addition, literature nearly vanished from the language learning curriculum in the midtwentieth century (Carter, 2007), and methods based on linguistics were given priority. Researchers make an intrigue to different goals of the literary text by representing the upsides of carrying literature into the language classroom as follows;

Long (1964, p. 3) said that writing in a more extensive sense is just methods of taking notes on the race, which consolidates history, science, verse, and books of the decimation. In a restricted sense,

\footnotetext{
${ }^{1}$ Corresponding author. Tel.: +66-085-024-6009

E-mail address: kampeeraphab.it@bru.ac.th
} 
writing is to spare an existence with craftsmanship additionally rundown, writing alludes to the statement of life as certainties and excellence. Writing is a record of life, considerations, feelings, and motivation of humankind or the profound history of manhood.

Juden (1994:5) concluded that literature is a book or writing that has been hailed as well. There are beauties in the languages, use of words with value into the literary stage and having good contents can convince the reader to bring enjoyment, consciousness, contemplations and feelings as indicated by the creator so as to comprehend the significance of the literature more clearly. In this manner, to specify the significant highlights of the writing abridged as follows: 1) Artistic in this element, the writing must be lovely in that of must mirror life in the genuine sense that is precise and wonderful. 2) Suggestive of literature won't be in a fixed way, however can be comprehended by accepting, the translation of writing depends on the forecasts of every individual. Forecasts may change as indicated by the energy about the peruser. 3) Permanent is worth noting that work that is literature which is very durable, said that it is popular and in the memory of readers in a long time not just highly regarded one day, today.

Thus, the significance and estimation of literary texts is not just media. On the off chance that things are concealed somewhere down in the hole between the letters also mirrors the intricate details of the creator's astuteness. Deep in the wisdom is the sincerity that the author reflects on himself and to the reader (Wongkul, 1997). Literary texts are the piece of human life. Each country that has grown up must have its own scholarly and literary tradition that is pretty much fortunate or unfortunate, and contingent upon the development of the psyches of the countries. Literary texts are the pointer of how high culture has developed and which period has the most elevated development.

The simple definition of a literary text is the writing of either prose and/or poetry, which if considering this definition, in principle, the first written poem or even a mail order item may also be called a literary text, hence to make the meaning more clear a literary text must be in a good writing style. This is the point of criticism and the most interesting idea (Mersand, 1973, p. 313). For this reason, literature is a communication tool for thinking, conveying imagination and expressing exquisite art. The studying or reading each literary piece makes the reader see the images of society, culture, politics and economy of the era in which the author has reflected through his perspective. Including making readers understand people's feelings about those situations as well.

For "Culture", it might signify "The aftereffect of an association of a gathering of individuals and to do any exercises in their gathering" (could conceivably be fruitful), however as a general rule, culture is conceived from a blend of multiculturalism to wind up one and is acknowledged in the general public (gatherings) such as 1) National Culture, 2) Industrial Culture, 3) Religious Culture, 4) Education Culture, and etc., which endeavors to give a short definition that is fitting, straightforward for "Cultural Awareness" is very troublesome. The literature and literary works are in this way steady with the way of life, and exceptionally helpful for considering language aptitudes in pretty much every viewpoint. Consequently, an understanding of cultural awareness that should be included in the content of literature is used as an initial lesson in practice.

\subsection{Literature review}

At present, literature and literary texts are essential to changing roles, which have a teaching model from transferring content to emphasize the learners to create knowledge by themselves.

\subsubsection{The reasons must be literature}

1. University Skills 
Students who studied literature and read for joy have a higher vocabulary, better perusing cognizance, and better relational abilities, for example, composting capacity. Relational abilities influence individuals in each aspect of their lived, from exploring relational connections to taking an interest in gatherings in the working environment to drafting interoffice updates or reports. At the point when students dissect literature, they figure out how to recognize circumstances and logical results and are applying basic reasoning aptitudes. Without acknowledging it, they look at the characters mentally or sociologically. They distinguish the characters' inspirations for their activities and transparent those activities to any ulterior intentions. When arranging an article on a work of literature, students use critical thinking aptitudes to concoct a postulation and finish on accumulating their paper. It takes examine abilities to uncover proof for their postulation from the content and academic analysis, and it takes authoritative aptitudes to show their contention in a cognizant, durable way (Lombardi, 2017).

\section{Higher Level Thinking Skills}

Numerous instructors pick literature-based educating in light of the fact that they feel that they center around higher-request thinking abilities than essential educating. Rather than driving youngsters to respond to pat inquiries concerning literature stories utilizing writing, urge kids to think profoundly and share thoughts regarding stories. True literary reading can improve vocabulary, perusing perception, perusing capacity, and language development. Likewise, literature-based instructing is more youngster focused than having an educator as a facilitator or mentor rather than "intellectual on stage". (Perles, 2017).

\section{Critical Thinking}

Lecture based on literature has a vital result on critical thinking development. A reader should acknowledge patterns inside the text, match details into those patterns, so relate them to different texts and experiences that are remembered (Madison, 1997). For the accompanying reasons, the reading of literature is famously amicable to the fundamental alternatives of crucial thinking. Firstly, the conceptual method of reading the literature requires expertise in critical thinking (Chi-An \& Shu-Ying, 2009). The reading of literature could be a dynamic process that involves readers to remember, retrieve and suppose their previous experiences or reminiscences so as to create text meanings. Even if doing thus, they have to prove the subsequent capacities: tell apart facts from opinions; recognize actual or implied definitions, and the sound of the narrator; locating details of the issues discussed; recognizing the actuating relationship or associations between the occasions or activities; distinguishing an inferential relationship from the discovered subtleties; being discerning of various perspectives; to make moral thinking and just decisions; and a large portion of all, to expand what they have gained from this strategy to other real-world or domains. In a particular context, the perusers apply what the critical thinking critical thinking call 'clarification,' 'examination,' 'combination,' 'argumentation,' 'understanding,' 'assessment,' 'critical thinking,' 'derivation' 'legitimate thinking' and 'application' (Brunt, 2005; Facione, 2007; Khatib, 2012; Lazere, 1987).

\section{Cultural Understanding}

Another advantage of reading literature is social advantages. Perusers live in general public. They can be affected by the negative parts of society. Yet, in literature, they realize that numerous characters originate from social classes, races, and ethnic gatherings (Rony, 2014). For nonnative English speakers, examining writing likewise with the investigation of English workmanship, reasoning, and financial matters give the beginner anthropologist a window to the spirit of English culture and traditions (Smith, 2017).

\section{Cognitive Strategy}


A key cognitive advantage of perusing writing is the improvement of reasoning skills. Tweens normally accept that there is "one truth" on the planet that isn't influenced by close to home inclinations or points of view. (Fraser, 2017).

\subsubsection{Benefits of literature}

Learning literature or literary texts has allowed us to study many aspects of what we read. Experience is the stories that occur in each era through the poet, the social culture, the study of poetic characteristics used these things gives us more experience as follows:

1. Literature helps knowledge in many areas to help build intelligence for readers, such as language, will make readers have knowledge of the meaning of language usage of each era, each region, a pattern of prosody each category History, chronicles, long stories, stories, native stories (Tongchuy, 2011).

2. Literature provides various emotional values because literature is the art of transmission. Feelings and emotions with poetry which has a life that makes the reader feel emotionally compliant get a taste of literature, aesthetics.

3. Literary texts give students real materials and their utilization in language classes enables understudies to improve learning, builds up their basic reasoning and upgrades their social training (Shtepani, 2012:13).

4. Refines the psyche and inspiring of the peruser to be higher and helping the brain to make individuals see instances of affliction, joy, and different life issues that make perusers see life too. Additional comprehension and the literature will embed the Dharma through the letters in order to show the brain of the peruser also.

\subsection{Previous Studies}

In brief, the layout of the properties of literature "1) Human creation, 2) Abstract of human life and experience, 3) Language use (composing and/or talking) as a mechanism of articulation, 4) Representing truth and Esthetic or tasteful worth, and 5) helpful for happiness and comprehension" (Much \& Retnaningdyah, 2011:9). There are numerous strategies that address the issues of EFL educators who are eager to use writing in their courses. Carter and Long (1991) looks at three essential ways to deal with show writing in the EFL classroom.

1. The Culture Model: The model gives a customary way to deal with the utilization of literary texts in the EFL classroom. It urges understudies to find and investigate social, literary and recorded components of the content. With the assistance of this structure, instructors mean to uncover explicit thoughts and points of view so that students can turn out to be progressively acquainted with different cultures and philosophies. These model anxieties the estimation of literature in epitomizing the gathered astuteness and "connections understudies with a scope of articulations which have allinclusive qualities over a long timeframe" (Talif and Jayakaran, 1994:16).

2. The Framework Language: This is a standout amongst the most mainstream techniques which have been named as "how to utilize the language" via Carter and Long (1991). This strategy will enable understudies to analyze the substance methodically and as More frameworks Language components, for example, immediate and circuitous words, are planned to educate in this model. Methodology for clouding works out, circling, content synopses, experimental writing, and pretending are the principle exercises that EFL instructors use to show semantic structures. Along these lines, the abstract objectives are decreased thusly of educating. Exercises engaged with the exercise. It has an increasingly incorporated instructor. Implies that the writing is inadequately assessed and language preparing is progressively significant in this pattern. 
3. The Personal Development Model : This model is a platform between the language types and social models. It highlights the use of language in the theoretical messages in the social setting. Understudies will in general express conclusions and sentiments about close to home encounters and social learning that are progressively applicable to the substance in the writing. Themes and points are finished hotspots for self-advancement. Cadorath and Harris (1998:188) outline the significance of this pattern, with the words "The message doesn't have any importance; I has just the bearing for perusers to make significance from the peruser's understanding." In this manner, the examination of artistic writings is also significant in this model.

\subsection{Research Objectives}

To examine the role of literature and literary texts in an EFL setting on different issues as pursues:

1. To investigate the attitudes of learners towards literature.

2. To discover the impact of literature and literary texts on cultural awareness and language skills in Thai EFL undergraduate students.

\section{Method}

\subsection{Research Sampling and Setting}

Literature as an instructive instrument in learning English as an unknown dialect and a wellspring of genuine material can be a convincing vehicle for language learning. It adds to the flourishment of understudies' fascinating thoughts and learning and improves English guidance.

Population: The population utilized in this research was English major undergraduate students of the Faculty of Humanities and Social Sciences, Buriram Rajabhat University in the academic year 2018. The students who have already enrolled in the poetry selection course, consisted of 40 third-year undergraduate students and 88 fourth-year undergraduate students, totaling 128 people.

Sample groups: The samples of the investigation were calculated using the Taro Yamane Method (Yamane, 1973: 727-728), and a simple random method selected 100 individuals.

Variables: The Independent variables were English major undergraduate students (EFL). Dependent variables were measured assessment by questionnaire.

\subsection{Instruments for data collection}

\subsubsection{Validity}

This phase involved documentary research of reviewing related theories and human resource management from textbooks, websites, journals, and related research.

Phase one: The questionnaire was adapted from other questionnaires of Abu Zahra, N.A., \& Farrah, M.A., furthermore, introduced to the exploration's board for any recommendations for development.

Phase two: The questionnaire was amended and balanced as per remarks and proposals made by the experts.

Phase three: After the experts had provided input and suggestions, the Item-Objective Congruence Index (IOC) was used to determine validity of the material. During this step three experts checked the questionnaire. 


\subsubsection{Reliability}

Phase one: A semi-structured interview using open-ended questions tested the quality of the content, language consistency, material scope, understanding questions and found the Item-Objective Congruence Index (IOC) above 0.50 .

Phase two: 20 close-ended questionnaire with a 5-point Likert scale (Likert, 1967); where 1 strongly disagree, 2 - disagree, 3 - neutral, 4 - agree, and 5 - strongly agree.

Phase three: The content validity and Index of Item-Objective Congruence (IOC) were controlled by the three experts of each inquiry was higher than 0.50 , and

Phase four: Tryout run with 30 EFL students, except for examples. Cronbach's alpha coefficient by item and the overall questionnaire was equal to 0.90 period of December 2017.

\section{Results}

The survey is examined by the Mean $\left(\mathrm{x}^{-}\right)$and Standard Deviation (SD) utilizing measurable bundles. The researchers differentiated the use of three levels of statistics according to the frequency range as follows:

$\begin{array}{lll}\text { High } & \text { use } & 3.50-5.00 \\ \text { Medium } & \text { use } & 2.50-3.49 \\ \text { Low } & \text { use } & 1.00-2.49\end{array}$

At last, an analysis of the content was used for interview which included translating, coding and sorting.

At last, an analysis of the content was used for interview which included translating, coding and sorting.

Table 1. General information

\begin{tabular}{lc}
\hline Gender & People \\
\hline Male & 20 \\
Female & 80 \\
Total & 100 \\
\hline
\end{tabular}

As shown by Table 1; the samples were male 20 people and female 80 people, an aggregate of 100 people respectively.

Table 2. Grade point average (GPA.)

\begin{tabular}{cccccc}
\hline Item & Sample & Minimum & Maximum & $\mathbf{x}^{-}$ & SD \\
\hline GPA. & 100 & 1.92 & 3.90 & 2.83 & 0.52 \\
\hline
\end{tabular}

From Table 2; it shown the range of grades within the sample groups. Minimum GPA was 1.92, and the maximum 3.90. Means was 2.83 with a standard derivation of 0.52 respectively. 
Table 3. Year

\begin{tabular}{lc}
\hline Year & Percentage \\
\hline Third year & 60 \\
Fourth year & 40 \\
Total & 100 \\
\hline
\end{tabular}

From Table 3; the number of third years EFL students represented 60 percentage and the fourth EFL grade students represented 40 percentage of the sample groups.

Table 4. The General attitudes of learners towards literary texts

\begin{tabular}{lccccc}
\hline Statement & Min. & Max. & $\mathbf{x}^{-}$ & SD & $\begin{array}{c}\text { Levels of } \\
\text { attitudes }\end{array}$ \\
\hline Language skills & 2.00 & 5.00 & 3.60 & 0.72 & High \\
Personal reflections & 2.00 & 5.00 & 3.49 & 0.75 & High \\
Cultural awareness & 2.00 & 5.00 & 3.57 & 0.71 & High \\
Total & 2.00 & 5.00 & 3.55 & 0.65 & High \\
\hline
\end{tabular}

From Table 4; the degree of visual view of students towards literary texts shown up as pursues. Considering the sub-elements of all three categories of attitudes of learners towards the literary texts, it was found that the students had a high level of positive attitudes with $\left(\mathrm{x}^{-}=3.55, \mathrm{SD}=0.65\right)$. When considered all three sequences in descending order, Language skills have $\left(\mathrm{x}^{-}=3.60, \mathrm{SD}=0.72\right)$, Culture awareness $\left(x^{-}=3.57, \mathrm{SD}=0.71\right)$ and Personal reflections $\left(\mathrm{x}^{-}=3.49, \mathrm{SD}=0.75\right)$ respectively.

Table 5. Literary texts improve learner's language skills

\begin{tabular}{|c|c|c|c|c|}
\hline Items & Statement & $\mathrm{x}^{-}$ & SD & Improving \\
\hline 1 & Literary texts enhance reading skills & 3.60 & 0.72 & High \\
\hline 2 & $\begin{array}{l}\text { Literary texts are one of the main resources of vocabulary } \\
\text { acquisition }\end{array}$ & 3.52 & 0.69 & High \\
\hline 3 & Literary texts enrich critical thinking skills & 3.59 & 0.77 & High \\
\hline 4 & Literary texts strengthen writing skills & 3.59 & 0.78 & High \\
\hline 5 & Literary texts improve speaking skills & 3.50 & 0.89 & High \\
\hline 6 & Literary texts develop social/communication skills & 3.58 & 0.83 & High \\
\hline 7 & Literary texts sharpen listening skills & 3.50 & 0.83 & High \\
\hline & Total & 3.55 & 0.59 & High \\
\hline
\end{tabular}

As can be seen from Table 5; improved learner's language skills at a high level $\left(\mathrm{x}^{-}=3.55, \mathrm{SD}=\right.$ $0.59)$. By enhance reading skills to be first priority $\left(\mathrm{x}^{-}=3.60, \mathrm{SD}=0.72\right)$, enrich strengthen writing $\left(\mathrm{x},-{ }^{-}=3.59, \mathrm{SD}=0.78\right)$, critical thinking skills $\left(\mathrm{x},-{ }^{-}=3.59, \mathrm{SD}=0.77\right)$, and develop social/communication skills $\left(\mathrm{x}^{-}=3.58, \mathrm{SD}=0.83\right)$ respectively.

Table 6. Literary texts improve learner's personal reflection

\begin{tabular}{|c|c|c|c|c|}
\hline Items & Statement & $\mathbf{x},-$ & SD & Improving \\
\hline 8 & Literary texts enhance reading skills & 3.66 & 0.81 & High \\
\hline 9 & $\begin{array}{l}\text { Literary texts are one of the main resources of vocabulary } \\
\text { acquisition }\end{array}$ & 3.49 & 0.80 & High \\
\hline 10 & Literary texts enrich critical thinking skills & 3.53 & 0.78 & High \\
\hline 11 & Literary texts strengthen writing skills & 3.64 & 0.84 & High \\
\hline 12 & Literary texts improve speaking skills & 3.49 & 0.94 & High \\
\hline 13 & Literary texts develop social/communication skills & 3.47 & 0.78 & High \\
\hline 14 & Literary texts sharpen listening skills & 3.44 & 0.78 & High \\
\hline & Total & 3.53 & 0.63 & High \\
\hline
\end{tabular}


From Table 6; improved learner's personal reflection at a high level $\left(\mathrm{x}^{-}=3.53, \mathrm{SD}=0.63\right)$. By enhance reading skills $\left(\mathrm{x}^{-}=3.66, \mathrm{SD}=0.81\right)$, strengthen writing skills $\left(\mathrm{x}^{-}=3.64, \mathrm{SD}=0.84\right)$, and enrich critical thinking skills $\left(\mathrm{x}^{-}=3.53, \mathrm{SD}=0.78\right)$ respectively.

Table 7. Literary texts improve learner's cultural awareness

\begin{tabular}{rlllc}
\hline Items & \multicolumn{1}{c}{ Statement } & $\mathbf{x}^{-}$ & SD & Improving \\
\hline 15 & $\begin{array}{l}\text { Literary texts enlighten the learners' knowledge about } \\
\text { other Cultures }\end{array}$ & 3.75 & 0.69 & High \\
16 & $\begin{array}{l}\text { Literary texts develop learners to understand about other } \\
\text { cultures }\end{array}$ & 3.62 & 0.83 & High \\
17 & $\begin{array}{l}\text { Literary texts assist learners to accept different } \\
\text { backgrounds and cultures }\end{array}$ & 3.70 & 0.89 & High \\
18 & $\begin{array}{l}\text { Literary texts encourage learners to tolerate cultural } \\
\text { differences }\end{array}$ & 3.59 & 0.88 & High \\
19 & $\begin{array}{l}\text { Literary texts encourage learners to accept cultural } \\
\text { differences }\end{array}$ & 3.60 & 0.79 & High \\
20 & $\begin{array}{l}\text { Literary texts help the development of intercultural } \\
\text { sensitivity } \\
\text { Total }\end{array}$ & 3.75 & 0.86 & High \\
\hline & $\quad 3.67$ & 0.65 & High \\
\hline
\end{tabular}

As the results from Table 7; found that improved cultural awareness at a high level $\left(\mathrm{x},{ }^{-}=3.67, \mathrm{SD}\right.$ $=0.65)$. By knowledge about other Cultures $\left(x^{-}=3.75, \mathrm{SD}=0.69\right)$, intercultural sensitivity $\left(\mathrm{x}^{-}{ }^{-}=\right.$ $3.75, \mathrm{SD}=0.86)$, different backgrounds and cultures $\left(\mathrm{x},{ }^{-}=3.70, \mathrm{SD}=0.89\right)$, and understand about other cultures $\left(\mathrm{x}^{-}=3.62, \mathrm{SD}=0.83\right)$ respectively.

\section{Discussion}

The aftereffects of the investigation the role of literature and literary texts found, so there's a coherence between the perspectives of EFL students in all classifications including cultural awareness and language skills and consistent with the research of (Fraser, 2017) with literature and literary texts are the improvement of reasoning skills (Cognitive Strategy). This investigation expects to impact the utilization of literary texts in the EFL classroom. The evidence indicates the research should be incorporated in the literature class were beneficial and desirable. EFL students likewise underline that are combination literature and literary texts with their courses influence them. It can likewise develop skills, personal reflection, and cultural awareness.

Literature is one of the principal assets utilized in educating EFL in the classroom since it tends to be an excellent instructive apparatus. Utilizing literature in language instructing is exceptionally invaluable, for it offers four advantages (Jayakaran, 1994; Rony, 2014; Talif, \& Tongchuy, 2011). As for the establishment, literature and literary texts give students access to the way of life of the language they consider and empowers them to pick up a new perspective on the unknown dialect culture. The literature presents relevant information; along these lines, students will pick up awareness uses and structures planned for local speakers. Abstract, give such a rich setting that shows lexical and linguistic things being used and in this way makes them progressively significant. Moreover, literature causes them to gain the certainty and confidence expected to utilize the language suddenly. Moreover, literature adds to gathering work exercises where those students share and include all in all class talk. This, as a result, gives instructors a decent shot for building up students' talking ability and enables them to address students' blunders in articulation during the demonstration of such exercises. In a word, a welcome departure from the agreeable, dynamic and persuading background. 


\section{Conclusion}

The research findings showed continuity between the perspectives of participant Thai EFL students. They all emphasized the advantages of using the literature and literary texts to incorporate the cultural awareness and language skills of the students. This research proved the value of literature and literary texts in an EFL classroom could be enhanced by making use of other specifications including literary texts enhance reading skills, literary texts strengthen writing skills, and literary texts enlighten the learners' knowledge about other Cultures. The introduction of literature and literary texts into EFL classrooms would also encourage students to develop their diverse skills. Language skills, personal reflections, and cultural awareness are the most important of these skills. In other words, the integrated use of literature and literary texts in an EFL classroom, and lets learners enhance their studies linguistic skills in a beneficial way, yet their awareness of culture in all its facets of discourse. A review of interviews with the participants revealed that gave a positive effect on the research. It was discovered that 10 students of EFL members had high frames of mind are as follows:

\section{Improvement Language skills}

There were certain improvements in speaking, listening, and reading skills in a review of interviews. In terms of speaking and listening, students were able to sustain contact over long periods of time during final discussions while they were unfamiliar with the literary elements of a text as opposed to the start of the course.

1. Exchanging my opinion in English is difficult, because I don't speak English well. But I think my English speaking skills are better than they were last year.

2. I become intrigued by English novels, possibly on the grounds that my English perusing capacity is improved.

3. I figured out how to peruse stories well, for instance, expedient and effective, and talk about them with one another.

\section{Improvement Personal reflections}

Towards the finish of the semester, students were required to compose a concise intelligent section on improvements to their way to deal with perusing and examining literary works, just as any improvements in the course. This information was utilized by the instructor to survey class targets and make changes in accordance with upgrade the limit of the students to lead significantly in English. This examination was seen as being generally positive in that understudies had the option to talk about a story all the more dispassionately utilizing the instructed components. There were three key factors that caused the researcher to feel that the subject had accomplished the ideal results - expanded language skills, expanded personal reflections, and expanded cultural awareness abilities (Table 4):

\section{Improvement Cultural awareness}

Short stories have significant substance that can assist students with getting all the more socially cognizant. When all is said in done, by making social correlations with characters, various things found in the stories, students have been able to think more critically about each story.

1. The first time I read the "Animals Farm," Animal farm generally also greatly influenced culture. Animal Farm has many pop culture references that typically go unnoticed.

2. I generally attempt to associate with the stories in a social manner, however now and again the fact is difficult to communicate. I can talk superior to some other students on this stage.

EFL students likewise underline that combination literature and literary texts with their courses influence them. It can likewise develop skills, personal reflection, and cultural awareness. 


\subsection{Recommendations}

In the teaching of literature and literary texts which is a subject that many people say is difficult or not interesting. It is already difficult. Therefore, teachers should have an understanding of teaching and learning by focusing on learners and recognizing the importance of applying strategies for learning literature and literary texts to EFL students on issues.

1. Since the samples in this investigation had a decent order of English, further examinations on this issue ought to be sought after with various gatherings of samples as it is asserted that literature is reasonable for prevalent understudies (Steinberg, 1995). It merits exploring whether the literature is helpful too which level of learning.

2. This investigation supported that studying literature and literary texts were as effective in terms of overall, the students who had a high level of positive attitudes in language skills, personal reflections, and cultural awareness ability. However, literature and literary texts seemed to have a better role in improve competence than the nonliterary texts. More studies are needed to confirm these results.

3. Finally, the researchers selected the mixing research methods. In further studies, the investigate might be given the experimental research of studied literature and literary texts, and select the texts to read according to their own interests.

\section{Ethics Committee Approval}

The authors confirm that the study does not need ethics committee approval according to the research integrity rules in their country. (Date of Confirmation: 02.06.2020)

\section{Acknowledgements}

This research was funded by Faculty of Humanities and Social Sciences, Buriram Rajabhat University, Thailand.

\section{References}

Abu Zahra, N.A., \& Farrah, M.A. (2016). Using Short Stories in the EFL Classroom. IUG Journal of Humanities Research, 24, 11-42.

Akarsu, O., \& Darıyemez, T. (2014). The reading habits of university students studying English language and literature in the digital age. Journal of Language and Linguistic Studies, 10(2), 85-99.

Armstrong, M. (2015). Using literature in an EFL context to teach language and culture. The Journal of Literature in Language Teaching, 4(2), 7-24.

Brunt, B. A. (2005). Critical Thinking in Nursing: An Integrated Review. Journal of Continuing Education in Nursing, 36, 60-67.

Cadorath, J. \& Harris, S. (1998). Unplanned Classroom Language and Teacher Training. ELT Journal, 52(3), 188-196.

Carter, R. (2007). Literature and language teaching 1986-2006: A review. International Journal of 
Applied Linguistics, 17(1), 3-13.

Carter, R. A. \& Long, M. N. (1991). Teaching Literature. London: Longman.

Chernetsova, E. \& Maslova, E. (2019). The Alien City Chronotope within the Scope of Toni Morrison's Jazz. 3L: Language, Linguistics, Literature, 25(1), 43-54.

Chi-An, T. \& Shu-Ying, C. (2009). Developing Critical Thinking through Literature Reading. Feng China Journal of Humanities and Social Science, 19, 283-317.

Dwyarie, R. \& Tjahjani, J. (2019). Intercultural Concepts in Place Cliché by Jacques Godbout. 3L: Language, Linguistics, Literature, 25(3), 137-149.

Fraser, T. R. (2017). Developmental Benefits of Reading Literature. Retrieved October 10,2017, from https://www.verywellfamily.com/developmental-benefits-of-reading-literature-3287753

Facione, P. A. (2007). Critical Thinking: What It Is and Why It Counts. Milbrae, CA: The California Academic Press.

Hamdan, S. \& Jalaluddin, D. (2019). Relationship Ideals in Charles Dickens' Great Expectations. 3L: Language, Linguistics, Literature, 25(3), 106-114.

Hismanoglu, M. (2005). Teaching English through Literature. Journal of Language and Linguistic Studies, 1(1), 53-66.

Juden, W. (1942-1997). Contemporary Thai Poetry Bibliography; Research Support Fund (TRF). Bangkok: Thailand Research Fund (TRF).

Khatib, M., Shokoufeh, R., \& Fathi, J. (2012). The Role of Literature in EFL Classroom from an EIL Perspective. Journal of Academic and Applied Studies, 2, 12-21.

Khatib, M. (2012). Critical Thinking Skills through Literary and Non-Literary Texts in English Course. International Journal of Linguistics, 4(4), 563-580.

Khatib, M., and Rahimi, A. R. (2012): Literature and language Teaching. Journal of Academic and Applied Studies, 2, 32-38.

Kırkgöz, Y. (2008). Using Poetry as a Model for Creating English poems. Journal of Language and Linguistic Studies, 4(2), 94-106.

Kuleli, M. (2019). Identification of translation procedures for culture specific items in a short story. Journal of Language and Linguistic Studies, 15(3), 1105-1121. Doi: 10.17263/jlls.631551 Lazere, D. (1987). Critical Thinking in College English Studies. ERIC Digest. ED 284275.

Likert, R. (1967). The Method of Constructing and Attitude Scale. In Reading in Fishbeic, M. (Ed.), Attitude Theory and Measurement (pp.90-95). New York: Wiley \& Son.

Lombardi, E. (2017). What Literature Can Teach Us Communication and research skills-and how to be a better human being. Retrieved July 9, 2017, from https://www.thoughtco.com/whatis-literature-740531

Madison, WI. (1997). Critical Thinking and Literature-Based Reading. Report. The Institute for 
Academic Excellence.

Mansouri, S. (2017). Welcome to the Desert of the Real: Resisting a Postcolonial Reality in the Modern Irish Novel. 3L: Language, Linguistics, Literature, 23(2), 41-57.

Much, K. \& Retnaningdyah, K. (2011). Literature in EFL Classroom. Retrieved October 10, 2017, from http://myteachingforum.blogspot.com

Ochieng, D. (2012). Sexism in language: Do fiction writers assign agentive and patient roles equally to male and female characters? The Journal of Language and Linguistic Studies, 8(2), 20-47. http://www.jlls.org/vol8no2/20-47.pdf

Özışık, B. Z., Yeşilyurt, S., \& Demiröz, H. (2019). Developing intercultural awareness in language teaching: Insights from EFL lecturers in Turkey. Journal of Language and Linguistic Studies, 15(4),

1436-1458. Doi: 10.17263/jlls.668546

Öz, H., \& Efecioğlu, E. (2015). Graphic novels: An alternative approach to teach English as a foreign language. Journal of Language and Linguistic Studies, 11(1), 75-90.

Perles, C. (2017). What Are the Advantages \& Disadvantages of the Literature-Based Approachto Teaching Reading?. Retrieved October 10, 2017, from

https://education.seattlepi.com/advantages- disadvantages-literaturebased-approach-teachingreading-3560.html

Pardede, P. (2011). Using short stories to teach language skills. Journal of English Teaching, 1, 14-27.

Rony, A. (2014). Benefits of Reading Literature. Retrieved October 18, 2017, from https://ezinearticles.com/?Benefits-of-Reading-Literature\&id=8427383

Shtepani, E. (2012). Overview on the Use of Literary Texts in EFL Classes. Lingua mobilis, 6(39), 7-14.

Smith, S. (2017). What Are the Benefits of English Literature? Retrieved November 19, 2017, rom https://www.theclassroom.com/benefits-english-literature-11890.html

Sohrabi, Z. \& Pirnajmuddin, H. (2017). John Donne's Metaphors of Self and Empire: A Cognitive Analysis. 3L: Language, Linguistics, Literature, 23(1), 14-26.

Solhi Andarab, M., \& Kesen Mutlu, A. (2019). Student questioning in literature circles: An investigation of forms of questioning among ELT students. Journal of Language and Linguistic Studies, 15(1), 326-338. Doi:10.17263/jlls.547754

Steinberg, E. R. (1995). Imaginative literature in composition classrooms? College English, 57, 266-280.

Talif, R. \& Jayakaran, M. (1994). Using Literature In An Advantaged Situation: Issue And Hrospects. The English Teacher Journal, 23, 1-16.

Taşdan, T. E. (2018). Intertextuality in Albert Camuses philosophy: "Let us imagine Sisyphus happy". 
Journal of Language and Linguistic Studies, 14(2), 173-182.

Tongchuy, S. (2011). Benefits of literature. Retrieved October 10, 2017, from http://www.mwit.ac.th/ saktong/learn4/44.pdf

Tso Wing-Bo, A. (2014). Teaching short stories to students of English as a foreign language (EFL) at tertiary level. Journal of Language and Linguistic Studies, 10(1), 111-117.

Velu, U. \& How, C. (2019). Symbolic Representation of Tun Dr Mahathir: Visual

Analysis of a Malaysian Short Film. 3L: Language, Linguistics, Literature, 25(4), 138-155.

Violetta-Irene, K. (2015), The Use of Literature in the Language Classroom: Methods and Aims.

International Journal of Information and Education Technology, 5, 74-79.

Wongkul, P. (1997). Literature. Bangkok: DokYa Publishing.

Yamane, T. (1973). Statistics: An Introductory Analysis (3rd ed.). New York: Harper and

Row Publication.

Yusof, S., Lazim, Z. \& Salehuddin, K. (2017). Teacher Trainees' Perspectives of Teaching Graphic

Novels to ESL Primary Schoolers. 3L: Language, Linguistics, Literature, 23(3), 81-96.

\section{İnglizce'nin yabancı dil olarak öğrenilmesi bağlamında edebiyat ve edebi metinlerin rolü: Kültürel farkındalık ve dil becerileri}

\section{$\ddot{O} z$}

$\mathrm{Bu}$ araştırmanın amacı 1) öğrencilerin edebiyata yönelik tutumlarını araştırmak ve 2) Tay EFL lisans öğrencilerinde edebiyat ve edebi metinlerin kültürel farkındalık ve dil becerileri üzerindeki etkisini keşfetmektir. Nitel ve nicel araştırma yapılandırmasının bir karıșımı benimsenmiştir Soyut bir içerik, Buriram Rajabhat Üniversitesi'ndeki 100 ana dili İngilizce olan bir EFL sınıfına koordine edildi. Bu okul, Tayland'n kuzeydoğusundaki üniversitelerden biridir. Örnekler basit bir rastgele örnekleme yöntemiyle seçildi. Yarı yapılandırılmış görüşmeler, analist tarafindan yapılan görseller ile yapıldı. Araştırma, Taylandlı EFL öğrencilerinin bakış açıları arasında tutarlılık olduğunu gösterdi. Hepsi, öğrencilerin kültürel farkındalık ve dil becerilerini bütünleştirmek için edebiyat ve edebi metinleri kullanmanın avantajlarına işaret etti.

Anahtar Sözcükler: Kültürel farkındalık; dil becerileri; edebi metinler; kişisel yansıma; İngilizce öğretmek

\section{AUTHOR BIODATA}

Chomphu Isariyawat is a lecturer at English Program, Faculty of Humanities and Social Sciences, Buriram Rajabhat University, Thailand.

Chaleomkiet Yenphech is a Ph.D. student in Linguistics of department of Foreign Languages, Faculty of Humanities, Mahachulalongkornrajavidyalaya University, Thailand. 
Kampeeraphab Intanoo is an assistant professor at English Program, Faculty of Humanities and Social Sciences, Buriram Rajabhat University, Thailand. 